\title{
THE PROPRIETOR-INVITEE RELATIONSHIP AND THE SUPERIOR-KNOWLEDGE REQUIREMENT
}

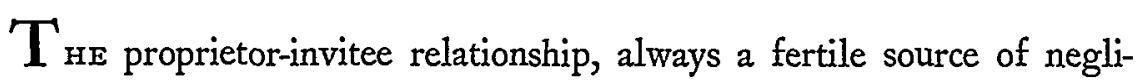
gence litigation, is governed by well-settled rules. When, however, a factual situation does not fit these rules, which may at times prove rigid and inflexible, it becomes imperative that they be disregarded and that fundamental negligence concepts be applied.

In a recent North Carolina case, Waters v. Harris, ${ }^{1}$ the plaintiff customer was injured when he slipped on a greasy substance on a warehouse floor while the proprietor was showing him used refrigerating equipment. In an action against the proprietor, the plairtiff alleged that there were no lighting facilities in the warehouse ${ }^{2}$ and that the floor was dark, greasy, and covered with trash. ${ }^{3}$ The trial court granted the defendant's motion for a nonsuit at the close of the plaintiff's evidence, holding that there was no evidence of the source of the greasy substance and no evidence from which the jury could reasonably find that the defendant had actual or constructive knowledge of the dangerous condition of the floor. 4 The Supreme Court of North Carolina, however, reversed the trial court, apparently on alternative grounds, none of which is clearly or unequivocally stated as the basis for its decision. ${ }^{5}$

The law governing a proprietor's duty to invitees requires that he exercise ordinary care to keep those portions of the premises which he should anticipate will be used by invitees ${ }^{6}$ in a reasonably safe condition and warn them of hidden perils and unsafe conditions which he can ascertain by reasonable inspection and supervision. ${ }^{7}$ Specifically, as to

\footnotetext{
${ }^{2} 250$ N.C. 701, I 10 S.E.2d 283 (I959).

3 The plaintiff presented evidence tending to show that, although it was ahout midday, it was "kind of dark that day"; that it was dark inside the warehouse; that the defendant did not turn on any lights and did not have a flashlight; that no lighting equipment was apparent; and that the only window was covered by a wooden shutter. 250 N.C. at 703 , I ro S.E.2d at 285 .

${ }^{3}$ Arguably, these conditions were as apparent to the plaintiff-invitee as to the defendant-proprietor.

' 250 N.C. at 705, rio S.E.2d at 286.

${ }^{5}$ See note 13 infra.

${ }^{\circ}$ Coston v. Skyland Hotel, 23 I N.C. 546, 57 S.E.2d 793 (1950); Leavister v. Jesse French \& Sons Piano Co., I 85 N.C. I52, II6 S.E. 405 (1923).

${ }^{7}$ E.g., Reese v. Piedmont, Inc., 240 N.C. 391,82 S.E.2d 365 (1954); Lee v. H.L. Green \& Co., 236 N.C. 83, 72 S.E.2d 33 (1952); Fanelty v. Rogers Jewelers, Inc., 230 N.C. 694,55 S.E.2d 493 (1949); Ross v. Sterling Drug Store, 225 N.C. 226, 34
} 
dangerous conditions not created ${ }^{8}$ by the proprietor, ${ }^{0}$ he is liable only if he $\mathrm{e}^{\mathrm{i0}}$ had actual notice of the condition or if it existed for such a length of time $^{11}$ that he should have known it existed and acted to remedy it. ${ }^{12}$

Application of this narrow rule to the Waters case supports the trial court's decision because that court held that there was no evidence upon which knowledge of the presence of the greasy substance could be imputed to the defendant. If this holding was not, in fact, overruled by the Supreme Court, ${ }^{13}$ then a consideration of only the foreign substance

S.E.2d 64 (1945); Bowden v. S.H. Kress \& Co., 198 N.C. 559, 152 S.E. 625 (1930). See generally, Prosser, Torts $\$ 78$ (2d ed. 1955); 2 HARPER \& JAMEs, TORTS $\$ 27.12$ (1956).

${ }^{8}$ Where the proprietor creates the dangerous condition, he has been held to have knowledge of it and no further notice is deemed necessary. Robinson v. F.W. Woolworth Co., 80 Mont. 431, 261 Pac. 253 (1927); Lee v. H.L. Green \& Co., sutpra note 7 (oiled floor). See, Copeland v. Phthisic, 245 N.C. 580,96 S.E.2d 697 (1957) (waxed floor); Hughes v. Anchor Enterprises, 245 N.C. 131, 95 S.E.2d 577 (1956) (cleaning and mopping). See generally, Annots., 63 A.L.R.2d 591 (r959); 63 A.L.R.2d 694 (1959).

Where the dangerous condition is a foreign substance, however, the plaintiff may prefer to allege general negligence, rather than specifically alleging creation of the condition, because it is often difficult to prove that the proprietor actually created the dangerous condition.

The same is true if the condition is created by an agent or one acting under the authority of the proprietor. See $e . g$., Caldwell v. Sears-Roebuck \& Co., 31 F. Supp. 888 (W.D. Pa. I940).

${ }^{10}$ If an agent of the proprietor were put on notice of the dangerous condition, such notice would be imputed to the proprietor. E.g., Vetter v. Great Atl. \& Pac. Tea Co., 322 Pa. 449, 185 Atl. 613 (1936).

${ }^{11}$ The nature of the busmess, the inherent dangers involved, the location of the defective condition, the opportunity for inspection, and the number of persons reasonably anticipated to accept the invitation are to be cousidered in determining what constitutes an unreasonable time for the unsafe condition to remain undetected. See, e.g., Moore v. American Stores Co., I69 Md. 54x, I 82 Atl. 436 (1936). "The greater the likelihood of danger . . . the greater is the amount of care required in making an inspection of premises to meet the standard of due care." Long v. Savin Rock Amusement Co., 14r Conn. 150, 153, 104 A.2d 221, 223 (1954). Negligent ignorance is in law equivalent to actual knowledge. Easler v. Downie Amusement Co., 125 Me. 334, 133 At1. 905 (1926).

${ }_{12}$ Montgomery Ward \& Co. v. Lamberson, 144 F.2d 97 (9th Cir. 1944); Kipp v. F.W. Woolworth \& Co., 150 App. Div. 283,134 N.Y. Supp. 646, appeal dismissed, 206 N.Y. 628, 99 N.E. I 109 (1912); Schwingle v. Kellenberger, 217 N.C. 577, 8 S.E.2d 918 (1940); Fox v. Great Atl. \& Pac. Tea Co., 209 N.C. 115,182 S.E. 662 (1935).

"Whether the floor was in fact safe, or reasonably so, is not the issue, but rather whether the defendant is chargeable with negligence for a failure to use reasonable and ordinary or due care to that end." Lander v. Sears, Roebuck \& Co., 14I Me. 422, 426, 44 A.2d 886,887 (1945).

${ }^{13}$ While the Supreme Court conceded that there was no direct evidence of the source of the grease, it implied that there might be indirect evidence from which a jury could reasonably find that the grease leaked from the refrigerating equipment. 250 N.C. at 
would not warrant recovery. ${ }^{14}$ However, when other factors ${ }^{15}$ contribute to the plaintiff's injury this narrow rule should not be decisive. Instead, all the circumstances should be examined to determine whether the conduct of the defendant was reasonable. Thus, in the Waters case, several additional factors, the most important of which was inadequate lighting, contributed to the plaintiff's injury. Although courts and commentators have somewhat neglected the importance of such factors

705, I Io S.E.2d at 286 . However, the only evidence offered concerning the source of the grease was the conjecture of the plaintiff and his laundryman (who was not present at the warehouse, but only examined the substance on the plaintiff's clothes), both of whom testified to the effect that it "could have been oil out of a compressor or motor or something like that." On the other hand, the plaintiff testified on cross-examination that there was no machinery where the grease was located. Therefore, even if it be conceded that the plaintiff satisfied the burden of going forward with the evidence as to the source of the foreign substance, his case on this theory of negligence is not very persuasive.

Also, the Supreme Court implied that there might be indirect evidence tending to show that the greasy substance had been on the floor long enough for knowledge of its presence to be imputed to the defendant. To support this, the court stated that the trash and the rough condition of the floor tended "to show neglect and inattention on the part of the defendants with respect to their duty to inaintain the warehouse floor in a reasonably safe condition..." 250 N.C. at 705,110 S.E.2d at $286-87$. It is submitted that this is an insufficient basis upon which to inpute knowledge of the presence of the greasy substance to the proprietor. It is generally held that no actionable negligence can arise out of a failure to sweep, clean, or inspect when there is no evidence tending to show that the foreign substance causing the fall would have been on the floor at the time of such action. Long v. Savin Rock Amusement Co., 141 Conn. 150, I04 A.2d 22 I (1954); O'Leary v. Smith, 255 Mass. I21, I50 N.E. 878 (1926); F.W. Woolworth Co. v. Goldston, 155 S.W.2d 830 (Tex. Civ. App. 1941) ; 65 C.J.S. Negligence $\$ 87$ ( 1950 ).

The third alternative ground relied upon by the Supreme Court in reversing the judgment of the trial court was the failure to provide adequate lighting. The court stated, "Negligence may consist in the failure so to light the premises as to protect from injury by reason of dangerous conditions which would not reasonably be discovered in the absence of such light." 250 N.C. at 706, I10 S.E.2d at 287 , quoting 65 C.J.S. Negligence $\$ 86$ (1950). It is submitted that this third ground of reversal will permit recovery by the plaintiff without overruling the holding of the trial court that there was no evidence upon which knowledge of the presence of the foreign substance could be imputed to the defendant.

14 Accord, Montgomery Ward \& Co. v. Snuggins, 103 F.2d 458 (8th Cir. 1939); Rawls v. Hochschild, Kohn \& Co., 207 Md. I 3 , II3 A.2d 405 (1955). Fanelty v. Rogers Jewelers, Inc., 230 N.C. 694, 55 S.E.2d 493 (1949); Brown v. Montgomery Ward \& Co., 2 I 7 N.C. 368,8 S.E. $2 d$ I 99 (1940); Cooke v. Great Atl. \& Pac. Tea Co., 204 N.C. 495 , I 68 S.E. 679 (1933).

The North Carolina Supreme Court seemed to think this was the basis for the trial court's finding for the defendant in the Waters case. 250 N.C. at 705,110 S.E.2d at 286 .

${ }^{15}$ See note 25 infra. 
in cases in which the proprietor had neither actual nor constructive notice of the extraneous substance, ${ }^{16}$ two conflicting views have emerged.

The orthodox view imposes liability upon the proprietor only if his knowledge of the danger at the time of the accident was superior to the knowledge of the invitee. ${ }^{17}$ According to this theory, actionable negligence cannot be based solely upon inadequate lighting because this condition is equally obvious to the proprietor and the invitee. ${ }^{18}$ The proprietor would be liable only where the existence of some other condition, of which he had actual or constructive notice, ${ }^{10}$ requires that he provide

${ }^{16}$ In most of the cases in which these additional factors appear, there is no reason for discussing them because the facts will justify an imputation of knowledge of the dangerous condition to the proprietor. See Hill Grocery Co. v. Hameker, 18 Ala. App. 84, 89 So. 850 (1921) (depression in floor; insufficient lighting); Kennedy v. Phillips, 319 Mo. 573, 5 S.W.2d 33 (1928) (concealed and unguarded elevator shaft); Drumwright v. North Carolina Theatres, Inc., 228 N.C. 325,45 S.E.2d 379 (1947) (concealed steps); Anderson v. Reidsville Amusement Co., 213 N.C. 130, 195 S.E. 386 (1938) (improperly waxed floor in dim light); Manley v. Haus, 113 Vt. 217, 32 A.2d 668 (1943) (unlighted stair well in garage); Raylass Chain Stores, Inc. v. De Jarnette, 163 Va. 938 , I78 S.E. 34 (1935) (stairway concenled by merchandise); Lindsey v. Bluefield Produce \& Provision Co., 9I W. Va. 118, I12 S.E. 3 10 (1922) (unguarded elevator shaft; dim light).

${ }^{17}$ McKeighan v. Kline's, Inc., 339 Mo. 523, 98 S.W.2d 555 (1936); Barrans v. Hogan, 62 N.M. 79, 304 P.2d 880 (1956); Revis v. Orr, 234 N.C. 158, 66 S.E.2d 652 (1951); Fort Worth \& D.C. Ry. v. Hambright, r30 S.W.2d 436 (Tex. Civ. App. 1939); Worth Food Markets, Inc. v. Le Baume, I12 S.W.2d ro89 (Tex. Civ. App. 1938) (dictum); 38 AM. JUR. Negligence $\$ 97$ (1941). See also, Keeton, Personal Injuries Resulting from $O_{p e n}$ and Obvious Conditions, I0o U. PA. L. REv. 629,634 (1952).

${ }^{18}$ Walker v. Greenberger, 63 Cal. App. 2d 457, 147 P.2d 105 (1944); Bisceglia v. Cunningham Drug Stores, 350 Mich. 159, 85 N.W.2d 91 (1957); Schwartz v. S.S. Kresge Co., 238 Mo. App. 1165, 185 S.W.2d 37 (1944); Revis v. Orr, 234 N.C. 158,66 S.E.2d 652 (1951); Robert E. McKee, Gen. Contractor, Inc., v. Patterson, 153 Tex. 517, 271 S.W.2d 391 (1954); Houston Nat'l Bank v. Adair, 146 Tex. 387,207 S.W.2d 374 (1948). See Restatement, Torts $\S 343$ (1934); id. $\$ 893$ (1939).

Although courts adhering to the superior-knowledge requirement are uniform in holding that there is no liability where the condition is open and obvious to the plaintiff, there is a great deal of unresolved conflict as to the grounds for the defendant's immunity. Some courts argue that there is no breach of duty by the proprietor because his duty extends only to warning the invitee of conditions which the latter would not, in the exercise of ordinary care, discover for himself. Other courts reason that, although the proprietor is negligent, the invitee, in encountering the obvious danger, is contributorily negligent as a matter of law. See generally, Comment, 5 BAYLOR L. Rev. 176 (1953).

${ }^{10}$ Beck v. Stauley Co. of America, 355 Pa. 608, 50 A.2d 306 (1947); De Clerico v. Gimbel Bros., 160 Pa. Super. 197, 50 A.2d 7I6 (1947). See Revis v. Orr, 234 N.C. 158, 66 S.E.2d 652 (1951).

It has been argued that lack of a duty in some instances "does not mean and 
adequate lighting to reveal that condition to an invitee who would not otherwise be fully cognizant of its presence. ${ }^{20}$ If this theory is applied to the Waters case, the proprietor is absolved of liability for the plaintiff's injury because he is not required to provide lighting in anticipation of some unknown danger. ${ }^{21}$

There is increasing dissatisfaction with the superior knowledge requirement, however. A number of courts have watered down this limitation on the proprietor's liability by refusing to find that the plaintiff had equal knowledge of the danger. ${ }^{22}$ Moreover, several recent cases

should not mean that the defendant has acted prudently. It simply means that even though he was guilty of anti-social conduct and conduct that should be discouraged, the achievement of other socially desirable ends or objectives that will be hindered by shifting the loss from the defendant to the plaintiff is a weightier consideration." Keeton, supra note 17 , at 632 .

For illustrations of cases invoking liability because of the proprietor's notice, see note 16 supra.

${ }^{20}$ The proprietor is under no duty to provide more illumination where the condition is obvious to the invitee despite the poor lighting. Reese v. Piedmont, Inc., 240 N.C. 391,82 S.E.2d 365 (I954); Benton v. United Bank Bldg. Co,, 223 N.C. 809, 28 S.E.2d 49x (x 944 ).

Negligence arising out of a failure to provide adequate lighting can be analogized to negligence arising out of a failure to sweep, clean, or inspect the premises. In these cases, there is no actionable negligence unless there is an intimation that such action would have revealed the dangerous condition. See cases cited note 13 supra.

${ }^{21}$ Cf., De Santis v. New Eng. Furn. Co., 132 Conn. 134, 42 A.2d 792 (1945); Thomas v. Merchants Nat'l Bank, 65 Ohio L. Abs. 353, I14 N.E.2d 863 (Ohio App. 1952); Dooley v. Economy Store, Io9 Vt. 138, I 94 Atl. 375 (1937).

"29 This result is often justified by imputing to the proprietor technical knowledge of the construction of the premises or appliances thereon or of the risk involved. See, e.g., Rose v. Melody Lane of Wilshire, 39 Cal. 2d 481, 247 P.2d 335 (I952) (amount of stress that safety pin in a swivel seat could withstand); Gobrecht v. Beckwith, 82 N.H. 415, 135 Atl. 20 (1926) (landlord held to knowledge that a gas heater gives off carbon monoxide); Haefeli v. Woodrich Eng'r Co., 255 N.Y. 442, I75 N.E. I23 (I93I) (strength of cement); Brown v. Montgomery Ward \& Co., 217 N.C. 368,8 S.E.2d 199 (1940) (escapability of machine oils in washing inachine); RESTATEMENT, TORTS $\$ 343$, comment $f$ (1934). See generally, Negligence, Knowledge, Minimum Standard of Knowledge, Duty To Know, 23 MiNN. L. REV. 628 (1939).

On the other hand, some courts have evaded the superior-knowledge limitation by concluding that there was an excusable lack of knowledge on behalf of the plaintiff. See, Tucker v. Tolerton \& Warfield Co., 249 Iowa 405, 86 N.W.2d 822 (I957) (plaintiff's eyes were not yet accustomed to the darkness); Dawes v. J.C. Penney \& Co., 236 S.W.2d 624 (Tex. Civ. App. 195I) (plaintiff might not notice the amount of mud on the floor); Blanks v. Southland Hotel, 149 Tex. 139, 229 S.W.2d 357 (1950) (accident occurred at night; plaintiff had used the stairs previously only during the daytime). Considerable leeway has been obtained in the application of this principle by use of language to the effect that apprehension of some danger should not be confused with full appreciation of the risk. Firestone Serv. Stores v. 
have abrogated the limitation and held the defendant liable, even though the invitee had equal knowledge of the danger, when the risk of harm was great enough and the situation could easily have been remedied. ${ }^{23}$ Arguably, recovery should be permitted even if the invitee had superior knowledge of the dangerous condition. The superior knowledge of one of the parties is treated as only one factor to be considered in determining whether, under all the circumstances, an unreasonable risk of harm to the invitee should have been foreseen. ${ }^{24}$ Other considerations, ${ }^{25}$ such as the invitee's justification in encountering the danger, ${ }^{26}$ are also pertinent. This approach to the problem thus utilizes

Gillen, 58 Ga. App. 782 , 199 S.E. 853 (1938); Loney v. Laramie Auto Co., 36 Wyo. 339, 255 Pac. 350 (1927).

${ }^{23}$ Dean v. Safeway Stores, 300 S.W.2d 43 I (Mo. 1957); Petera v. Railway Exch. Bldg., 42 S.W.2d 947 (Mo. App. 193I); 2 HARPER \& JAMES, op. cit. silpra note $7, \S 27.3$. See Markee v. Turner, 140 Conn. 7or, 103 A.2d 533 (1954); Williamson v. Derry Elect. Co., 89 N.H. 216 , 196 Atl. 265 (1938); Renfro Drug Co. v. Jackson, 8I S.W.2d ror (Tex. Civ. App. 1935); Konopka v. Montgomery Ward \& Co., I 33 W. Va. 775, 58 S.E.2d 228 (1950).

24 2 HARPER \& JAMES, op. cit. supra note $7, \$ 27.13$ n.23.

${ }^{25}$ These additional considerations may bear on one or both of the distinct lines of duty involved-that is, the proprietor's duty to keep the premises in a reasonably safe condition and the invitee's duty to exercise reasonable care to protect himself.

Factors which would be considered in determining whether there has been a breach of duty on the part of the proprietor include the character of the premises (warehouse or super market), the number of invitees whose presence should reasonably be anticipated, the precautions taken, the location of the danger, the reasonable safety with which the danger can be encountered by one who knows of the risk, the alternative means provided whereby the invitation may be accepted without encountering the danger, the presence and location of distractions, and the feasibility of removing the source of danger. See, e.g., Palmer v. Boston Penny Sav. Bank, 301 Mass. 540, 17 N.E.2d 899 (1938); Dean v. Safeway Stores, 300 S.W.2d 43 (Mo. I957); Petera v. Railway Exch. Bldg., 42 S.W.2d 947 (Mo. App. x93 I); Williamson v. Derry Elect. Co., 89 N.H. 216, 196 Atl. 265 (1938).

Illustrative factors bearing on whether there has been a breach of the invitee's duty are contained in: Wilson v. Raider, 317 Mass. 23, 56 N.E.2d 887 (1944) (express or implied invitation); Polm v. Hession, 363 Pa. 494, 70 A.2d 311 (1950) (the degree of darkness); Vetter v. Great Atl. \& Pac. Tea Co., 322 Pa. 449, 185 Atl. 613 (r936) (invitee's right to assume that the premises are safe); Kerr v. Bullock's, Inc., 75 Cal. App. 2d 277, 170 P.2d 966 (1946) (the reasonable safety with which the danger can be encountered); and Campbell v. Weathers, 153 Kan. 316, III P.2d 72 (1941) (opportunity to avoid the danger). "[M]ere knowledge of the dangerous condition ... was not alone sufficient to bar a recovery, unless the hazard resulting from its use was so imminent that no reasonably prudent person would have made the attempt." Southern Pac. Co., v. McCready, 47 F.2d 673, 677 (9th Cir. x 931).

${ }^{20}$ In view of the factors present in the Waters case- that the proprietor expressly invited and personally led the invitee into the building, that the invitee was following immediately behind the proprietor in the latter's chosen route and speed, and that the invitee was given no warning of danger (other than the lack of adequate lighting) at 
fundamental negligence concepts, rather than narrow, inflexible rules, to determine the question of liability.

Applied to the Waters case, a jury might reasonably find the proprietor negligent on the ground that his conduct threatened a foreseeable result ${ }^{27}$ involving an unreasonable risk of harm to the plaintiff. ${ }^{28}$ If due care required that the proprietor furnish more light, and he failed to remedy that source of danger, he should be liable for the resulting harm, even if his knowledge of the dangerous condition was no greater than that of the invitee. ${ }^{29}$

While the superior-knowledge limitation on the landowner's liability enjoys long-standing support, ${ }^{30}$ it should not be decisive in all cases. ${ }^{31}$ Rather, the factual situation in each case should determine its applicability. The $W$ aters case is a cogent illustration. The proprietor has ample opportunity to exercise deliberate judgment in providing suffcient lighting facilities. Moreover, under modern conditions, there is no justification for inadequate lighting of business premises. The proprietor is under a duty to make his business premises reasonably safe. This duty should include maintenance of adequate lighting facilities, enabling the invitee to ascertain the actual condition of the premises and intelligently decide if he should "accept the invitation." Poor illumi-

any time prior to the accident-a jury might reasonably find that the plaintiff was justified in relying on the defendant's performance of his duty to maintain the premises in such a reasonably safe condition that no light was necessary for the contemplated uses thereof and for the purposes for which the invitation was extended.

${ }^{27}$ The court stated that "it was reasonably foreseeable" that grease and oil might leak from the motors and moving parts of the secondhand refrigerating equipment. 250 N.C. at 706, I ro S.E.2d at 287 (dictum).

${ }^{28}$ It is submitted that this finding of negligence should be allowed even though the foreseeable result might be found to have been brought about by an unforeseeable cause. See Sledge v. Wagoner, 248 N.C. $63 x$, x04 S.E.2d x 95 (x958). See generally, Prosser, ToRTs $\$ \$ 48-49$ (2d ed. I 955), especially pp. 278-80; Comment, 196o Duke L.J. 88.

${ }^{20}$ Accord, Dean v. Safeway Stores, 300 S.W.2d 43 I (Mo. 1957); Petera v. Railway Exch. Bldg., 42 S.W.2d 947 (Mo. App. 193I). See, e.g., Markee v. Turner, 140 Conn. 7or, ro3, A.2d 533 (r954); Nelson v. Great Atl. \& Pac. Tea Co., 48 N.J. Super. 300, 137 A.2d 599 (App. Div. 1958); Renfro Drug Co. v. Jackson, 8 I S.W.2d ror (Tex. Civ. App. 1935); O'Flaherty v. Tarrou, x30 W. Va. 326, 43 S.E.2d 392 (I947). ${ }^{30}$ See notes 17 \& 18 supra.

${ }^{31}$ Although these modifications would nullify the superior-knowledge requirement as a strict limitation on the proprietor's liability, it would leave intact most of his traditional protection. Most of the decisions denying liabilty under the orthodox superiorknowledge theory could be equally explainable either on a finding that the invitee was contributorily negligent or on an absence of a finding that the proprietor acted unreasonably.

${ }^{32}$ Cf., Restatement, ToRTs $\$ 343$, comment $a$ (I934). 
476

nation deprives the invitee "of his opportunity to guard against hazards which could not otherwise be obviated by the proprietor."33

${ }^{33}$ Malone, Contributory Negligence and the Landowner Cases, 29 MiNN. L. REv. 61,82 (1945). 